九州大学学術情報リポジトリ

Kyushu University Institutional Repository

\title{
On the Basic Features of Farming System in the Mekong Delta-Vietnam
}

Hien Nguyen, Thi Minh

Laboratory of Quantitative Analysis of Agricultural Economics, Devision of Industrial

Organization of Agribusiness, Department of Agricultural and Resource Economics, Graduate School of Bioresource and Bioenvironmental Sciences, Kyushu University

Kawaguchi, Tsunemasa

Laboratory of Quantitative Analysis of Agricultural Economics, Devision of Industrial Organization of Agribusiness, Department of Agricultural and Resource Economics, Faculty of Agriculture, Kyushu University

https://doi.org/10.5109/24472

出版情報 : 九州大学大学院農学研究院紀要. 47 (1)，pp.195-204，2002-10-30. Kyushu University バージョン：

権利関係 : 


\title{
On the Basic Features of Farming System in the Mekong Delta-Vietnam
}

\author{
Hien NGUYEN Thi Minh* and Tsunemasa KAWAGUCHI
}

\author{
Laboratory of Quantitative Analysis of Agricultural Economics, Division of Industrial \\ Organization of Agribusiness, Department of Agricultural and Resource Economics, \\ Faculty of Agriculture, Kyushu University, Fukuoka 812-8581, Japan. \\ (Received June 26, 2002 and accepted July 12, 2002)
}

\begin{abstract}
Occupying about $12 \%$ of total land area of Vietnam, and $22 \%$ of its total population, The Mekong Delta contributes about $60 \%$ of aquaculture production, nearly $50 \%$ of the food production, and $70 \%$ of exported rice. Mekong Delta is considered as the most important agricultural region in Vietnam. Therefore, a deep understanding about characteristics of farming systems, main problems and constraints for the development of farming systems in Mekong Delta is always very necessary for any further research in farming systems of Mekong Delta. The paper is to overview some main features of Mekong Delta. The natural features such as geography, climate, soil conditions and the latest socio-economic conditions like population, education, income of farming systems are briefly introduced. The classification of agro-ecological region; the main production systems, the land use systems are described here. Then some main problems and constraints that hinder from development of farming system in Mekong Delta are also mentioned.
\end{abstract}

\section{INTRODUCTION}

Mekong Delta has very long history. It was formed about 10,000 years ago, but its exploitation started only about 300 years ago. The development of farming system in the Mekong Delta is closely linked to the natural resources, canal excavation, the process of settlement and land reclamation, the past war and the government policies (Sanh et al., 1998). Characteristic of the Mekong Delta is the rice-based farming system. There are relations among crop, livestock, and fish in the system. The main crop in the Mekong Delta is rice. The soil, climate and other natural conditions are suitable for rice production. In the process of development of farming systems in the Mekong Delta, farmers changed their rice mono crop using traditional varieties with long duration of 180 to 210 days and low yield to two rice crops using modern short duration varieties with higher yield. Besides the rice cultivation, nowadays, the farming systems have been improved and diversified. Farmers integrated other crops after two rice seasons such as mung bean, soybean, corn, vegetable, or introduced new cropping pattern such as rice cropping with fish, shrimp or duck. Even somewhere rice has been switched to other crops such as fruit tree, vegetable, watermelon. On the acid sulphate soils forest trees, cashew, pineapple, sugarcane, jute can be one of the choices that provide an income for farmers. A deep understanding about characteristics of farming systems, main problems and constraints

* Laboratory of Quantitative Analysis of Agricultural Economics, Division of Industrial Organization of Agribusiness, Department of Agricultural and Resource Economics, Graduate School of Bioresource and Bioenvironmental Sciences, Kyushu University. 
for the development of farming systems in the Mekong Delta is always very necessary for any further research in farming systems of the Mekong Delta.

\section{AN OUTLINE OF NATURAL AND SOCIO-ECONOMIC FEATURES OF THE MEKONG DELTA}

\section{Geographical location of the Mekong Delta}

As known that any delta is the product of a river, generally big one. The Mekong Delta lies at the estuary of the Mekong River, one of the biggest rivers in Southeast Asia $(4,220 \mathrm{~km})$, which flows through six countries, namely, China, Burma, Thailand, Laos, Cambodia and Vietnam. The Mekong Delta is the last section of the Mekong River basin. The Mekong Delta includes the Long An, Tien Giang, Ben Tre, Vinh Long, Tra Vinh, Dong Thap, An Giang, Kien Giang, Can Tho, Soc Trang, Bac Lieu and Ca Mau province (Thao, 1997). That is a plain zone with natural area of $39,568 \mathrm{~km}^{2}$. Except areas of small mountain in An Giang province and the terrace of Long An province, the plain of Mekong is rather flat with low altitude within $0.5-0.8$ meter on sea level. To the North, the Delta borders with Cambodia, to the East with the Vam Co River, to the South with the South China Sea, and to the West with the Gulf of Thailand. The location and provinces of

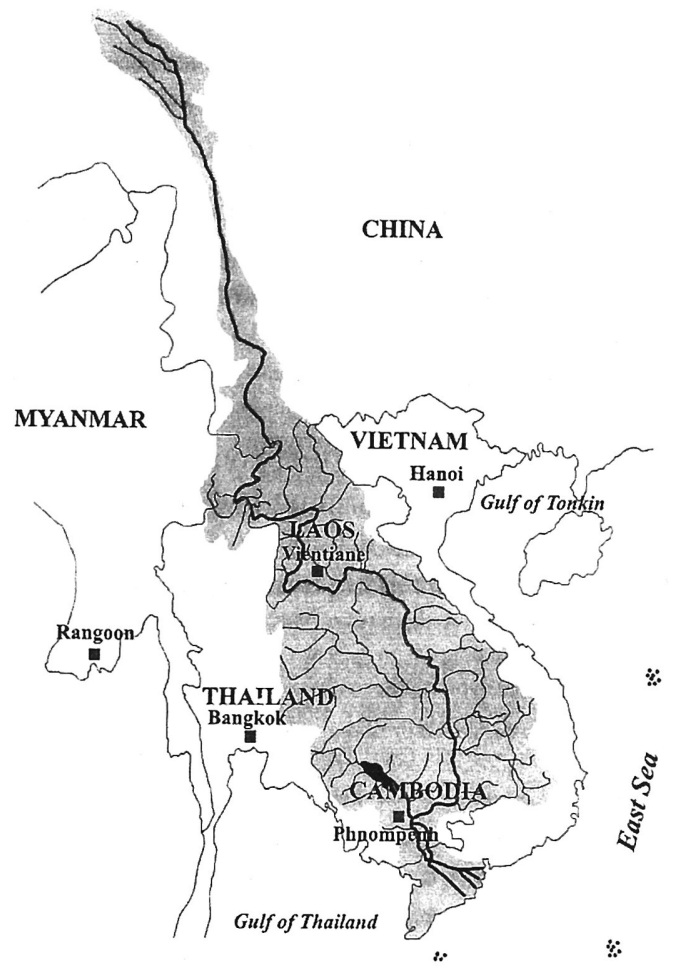

Fig. 1. The Mekong Delta 
Mekong Delta have been presented in Figure 1 and Figure 2

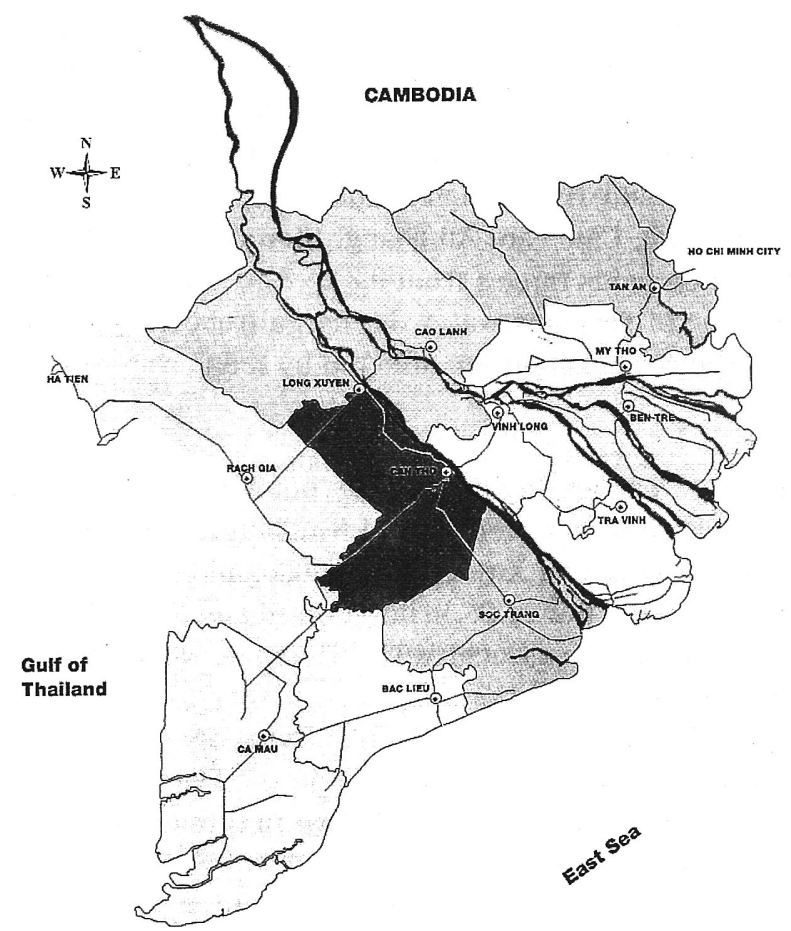

Fig. 2 The provinces of the Mekong Delta

\section{Climate}

The Mekong Delta has a monsoon tropical semi-equatorial climate. The yearly average temperature is about $27^{\circ} \mathrm{C}$. There are two distinct seasons: dry season lasts from November to April and rainy season lasts from May to October.

The rainfall distribution varies by location and season. The average annual rainfall is about $1,600 \mathrm{~mm}$. The highest rainfall is in the Western part with the mean of 2,000 to $2,500 \mathrm{~mm}$ and lowest in Central part with mean of $1,500 \mathrm{~mm}$. Ninety percent to 94 percent of the total rainfall is concentrated in the rainy season. Rainfall is usually evenly distributed in June to October or November. In the Mekong Delta, the summer monsoon brings $5-6$ months of rainfall above $100 \mathrm{~mm} /$ month. October is the wettest month of the year.

\section{Water resource}

Main fresh water sources are rainfall, the Mekong river and Vam Co river systems as well as underground water. In the Mekong Delta, the principal crop is rice. In dry season, 
rice production is limited because of saline water in coastal zones. On the contrary, a part of the Mekong Delta is annually affected by inundation of the Mekong River, specially for the summer-autumn seasonal crop.

Mekong Delta is famous with dense river, canal, ditches system. The water level in the Mekong Delta is influenced by the flow of the Mekong River and South China Sea. The hydrology is determined by rainfall, upstream discharge and tidal fluctuation. Almost every year, the Mekong Delta suffers flooding, with flooded areas of 1.4-1.9 million hectares, depending on whether the flood is small or large. The main flood prone areas in the Mekong Delta are Dong Thap, The Long Xuyen quadrangle (An Giang province), and low land of western Hau Giang river which include 8 provinces: Long An, Dong Thap, Tien Giang, Ben Tre, Vinh Long, Can Tho, An Giang, Kien Giang. In the flooding period, the water depth in the paddy fields ranges from 0.3 to $3 \mathrm{~m}$. During the dry season, irrigation water is scarce because of very low water discharge from the Mekong River, and as the result, large parts of the coastal areas are affected by saline water intrusion.

\section{Soil}

Soils in the Mekong Delta are highly variable, but alluvial, acid sulfate, and saline soils predominate. Acid sulfate soils cover some 1.6 million ha, or $40 \%$ of soils in the delta, mainly in the Plain of Reeds, Long Xuyen Quadrangle, and Ca Mau Peninsula. The soil is rich in humus and total $\mathrm{N}$, but low in $\mathrm{P}$. In addition $\mathrm{Al}$ and $\mathrm{Fe}$ toxicities limit yield. These soils contain high concentration of acid with $\mathrm{pH}$ values ranging from 2.26 to 3.54 thus posing big constraints to rice cultivation.

Alluvial soils, prevalent in $30 \%$ of the Mekong Delta, are concentrated along the banks of the Tien and Hau Rivers. That is the best soil in the Delta with humus content of $2 \%$, total $\mathrm{N}$ of 0.1 to $0.25 \%$, and medium $\mathrm{P}$ and $\mathrm{K}$. Two to three crops can be grown on these soils each year. The alluvial soils are suitable for rice cultivation.

Saline soils found along the coastal region cover an area of 808,749 ha (21\% of the Mekong Delta). The soils are rich in humus, N, and clay (55-60\%), but with a high salt content. The remaining soils are upland and mountainous peat soils (Sanh et al., 1998). Table 1 provides some data on natural area, area of land for agriculture and population in each province in Mekong Delta in year of 2000.

\section{The socio-economic features}

The population of Vietnam in the year of 2000 was about 77.7 million with an average density of $228 / \mathrm{km}^{2}$. Population growth rate was about $2.2 \%$. The population is basically rural and concentrated in the two rice-growing deltas: the Red River Delta in the North and the Mekong Delta in the South. Total labor force is 35 million, with about 21.5 million labor engaged in agriculture. Total population in Mekong Delta is 16.37 million, occupy about $22 \%$ population of whole country, $80 \%$ of which now living in rural area. About 5.4 million people (nearly $36 \%$ of the population) belong to the active labor force in the agricultural sector, which is concentrating on growing rice (GSO, 2000a). Data on population of Mekong Delta and of each province in Mekong Delta is presented in Table 1.

The farm sizes in Mekong Delta depend on the population and land resource of each province. The average farm size is 1.0 to $1.2 \mathrm{ha}$. The small sizes of farm are found in the provinces with high population densities like Tien Giang, Vinh Long, Ben Tre. The 
Table 1. Natural land, agricultural land and population by province in Mekong Delta

\begin{tabular}{cccc}
\hline Region and province & $\begin{array}{l}\text { Natural area } \\
(\mathbf{1 0 0 0} \mathbf{h})\end{array}$ & $\begin{array}{l}\text { Agricultural area } \\
\mathbf{( 1 0 0 0 \mathbf { h } )}\end{array}$ & $\begin{array}{c}\text { Population } \\
\text { (Thousand persons) }\end{array}$ \\
\hline Mekong Delta & $\mathbf{3 9 7 1 . 3}$ & $\mathbf{2 9 7 0 . 2}$ & $\mathbf{1 6 3 6 5 . 9}$ \\
Long An & 449.2 & 331.3 & 1330.4 \\
Dong Thap & 323.8 & 249.4 & 1580.5 \\
An Giang & 340.6 & 256.2 & 2080.3 \\
Tien Giang & 236.7 & 181.5 & 1620.7 \\
Vinh Long & 147.5 & 119.6 & 1018.9 \\
Ben Tre & 231.5 & 167.3 & 1307.2 \\
Kien Giang & 626.9 & 402.6 & 1528.1 \\
Can tho & 298.6 & 254.6 & 1838.7 \\
Tra Vinh & 222.6 & 182.0 & 982.1 \\
Soc Trang & 322.3 & 263.8 & 1193.9 \\
Bac Lieu & 252.1 & 210.6 & 745.2 \\
Ca Mau & 519.5 & 351.3 & 1139.9 \\
\hline
\end{tabular}

Source: Statistical yearbook 2000

average size of farm in these provinces is $0.5-0.6$ ha. While the per capita income ranges from 120 to 125 USD/year. Generally, the level of education of farmer in Mekong Delta is still lower comparing to average level in whole country. The rate of illiterate of reading and writing of 10 years old up accounts to 18 and 13 percent, respectively.

\section{AGRO-ECOLOGICAL REGIONAL CLASSIFICATION}

According to the classification of agro-ecological characteristics (source: the same with table 2) there are regions of four geomorphologic types in the Mekong Delta:

Table 2. The main agro-ecological zones in Mekong Delta, Vietnam

\begin{tabular}{llrr}
\hline Geomorphology & Agro-ecological zones & $\begin{array}{c}\text { Estimated } \\
\text { Area (ha) }\end{array}$ & $\begin{array}{l}\text { Percentage } \\
\text { (\%) }\end{array}$ \\
\hline 1/ Flood Plain & - Riverine flood plain & 1200000 & 29,18 \\
& - Closed flood plain (Plain of Reeds) & 496000 & 10,40 \\
& - Open flood plain & 217580 & 5,50 \\
\hline 2/ Coastal Plain & - High coastal plain & 669800 & 17,80 \\
& - Peninsula low coastal plain & 648000 & 16,30 \\
& - Tidally-inundated coastal plain & 195300 & 5,10 \\
\hline 3/ Ancient Alluvial Terrace & - Ancient alluvial terrace & 216000 & 5,40 \\
\hline 4/ Hill and mountains & - An giang mountain area & 123500 & 3,00 \\
\hline Source: The legend on the agro-ecological map of Mekong delta, The National Institute of \\
Agricultural Planning and Projection of Vietnam, Hanoi, 1987
\end{tabular}


- Flood plain

- Coastal plain

- Ancient alluvial terrace

- Hill and mountains

These types can be divided into nine agro-ecological zones as shown in Table 2. On lower level, each agro-ecological zone is divided again into different sub zones and many ecological units. The criteria of classification are based on the differences of geomorphologic condition, kind of soils, depth of inundation, time of inundation, water availability for irrigation, rainfall, duration of rainy season cropping, probability of dry spell in rainy season, land use, etc.

Among these nine agro-ecological zones, the riverine flood plain, the closed flood plain (the Plain of Reeds), the open flood plain (the Long Xuyen quadrangle), the high coastal plain and the peninsular low coastal plain are the main ones that are devoted to rice production in Mekong Delta.

\section{MAIN PRODUCTION SYSTEMS IN MEKONG DELTA}

Production systems in Mekong Delta can be divided into five main systems: 1) Forestry systems, 2) rainfed systems, 3) The floating-rice based systems, 4) The irrigated systems, and 5) Garden systems (Son, 1998)

When the exploitation of Mekong Delta was started 300 years ago, forests occupied more than half of the total area of the Mekong Delta, mainly on the problem soil areas. Mangrove and Melaleuca forests were the main part of forest at that time. Over time, farmers gradually changed from exploiting extensively natural resource to implementing agriculture, forestry, fishery and farming activities inside the forest ecosystems.

The rainfed system is the oldest cultivated system in the Delta. The deep-water rice system, used where the water depth ranges from 50 to $100 \mathrm{~cm}$, and the rainy season rice system on problem soils are the two main rice-based subsystems. Farmers cultivating in those lands use local varieties with the characteristics of low yield but low level of input investment. Another form of rainfed systems is the aquatic cultivation in the coastal areas.

The floating rice system has been starting since 1920s. It has been applied in the flooded areas that were annually inundated with more than one meter of water. With this system farmers do not use fertilizer and pesticide, and yield is quite low. Nowadays this system is only existing on small area, because the irrigation and drainage system has been improved. Therefore, floating rice is rapidly being replaced by irrigated rice.

The irrigated system covers nearly all the areas near the Mekong River and other ones served by the irrigation system. This system is a very diversified system. The farming system is very abundant and plentiful depending on the geography of each area, and development of market. In the areas where farmers are not affected by flood or soil problem, they grow two or three crops per year. Farm enterprises are quite diverse including animal husbandry and non-farm activities. Agricultural chemicals are applied at the rather high level. The level of mechanization in agricultural production is still low, only concentrating on some activities such as land preparation, irrigation and threshing. 
The last system in Mekong Delta is garden production system. In the central part of the delta, where there are favorable environmental conditions, farmers grow fruit trees in home gardens around their house. The kinds of fruit grown in garden are different by the regions depending on the markets and soil conditions. In the garden production system, mixed varieties of fruit trees are combined with aquaculture.

\section{LAND USE AND CROPPING PATTERN IN MEKONG DELTA}

Since the promulgation of the new policies-" doi moi" (renovation) in agriculture, the farming system in Mekong Delta has remarkably changed. Almost all farm activities shifted from intensive mono cultivation to diversified and intensive cultivation (Sanh et al., 1998). Various rice growing methods and new modern rice varieties have been introduced and applied. Fruit tree gardens have been created a long the river banks, and the area is increasing. The figure 3 shows the land use structure and production systems in Mekong Delta

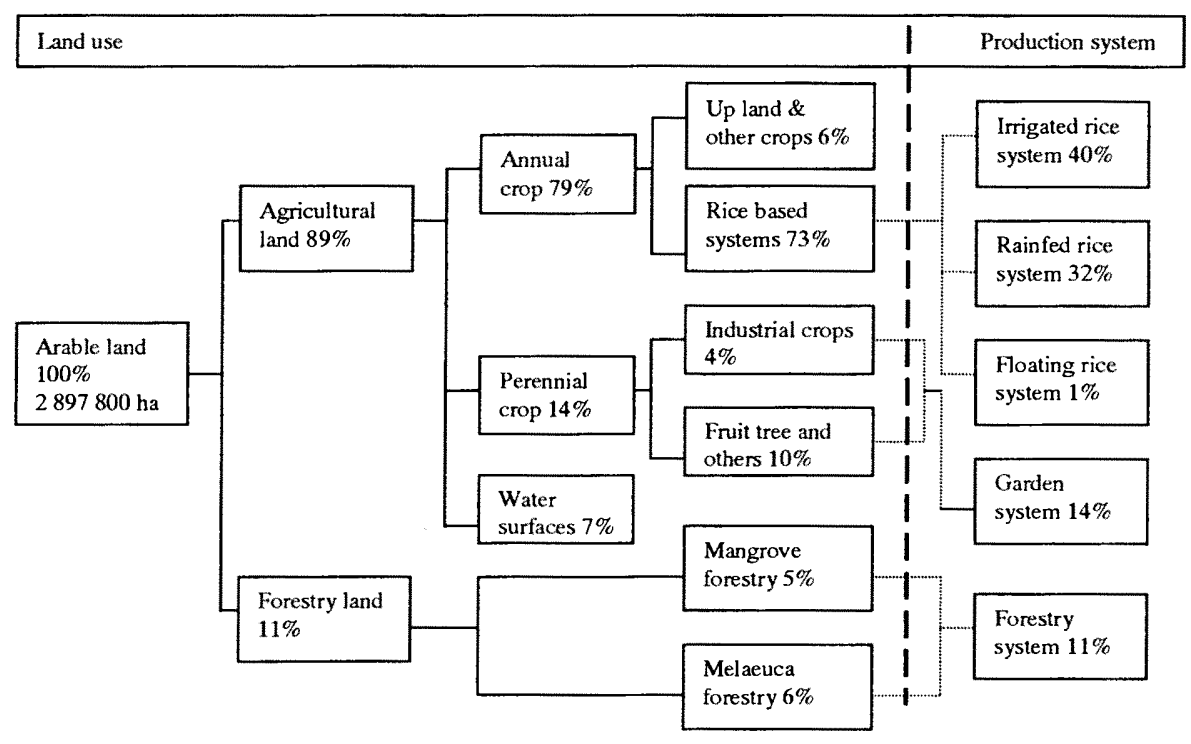

Fig 3. Land use structure and production systems in Mekong Delta

Rice is the most important crop for the Mekong Delta farmers. About half of the rice produced in Vietnam comes from the Mekong Delta. The increase in rice production was due to: (1) using of short duration modern varieties that can give good harvest and avoid annual flood; (2) expanding the irrigation scheme, that helps to cope some problem of water both in dry and rainy seasons; (3) Use of additional fertilizers and pesticides.

Although the soil of the Mekong Delta is not very suitable for production of soybean, 
groundnut and tobacco, others industrial crops like sugarcane, kenaf, jute, coconut and cocoa are very well adapted to the Mekong Delta. The coconut production in Mekong Delta occupies $80 \%$ total coconut area in Vietnam and $77 \%$ total output (Cuc, 1995, GSO-DAFF, 2000). Sugarcane is suitable to the acid sulphate soil region, and it can be an alternative bringing a good income for farmers.

Mekong Delta is the place of many exotic tropical fruit trees. The Mekong Delta farmers have many experiences in growing fruit trees. The area under the fruit trees has been increasing by the time. Traditionally, Mekong farmers have grown many kinds of fruit trees like longan, mangosteen, rambutan, durian, and so on in their orchards. The farmers believe this helps to maintain stable income around the year. The Mekong Delta now has a total area of 325,000 ha under fruit tree cultivation. However, the income of farmers from orchard is still low due to low and fluctuated price and poor post harvesting technology. The introduction of artificially induced fruit growing techniques and improved post-harvest maintenance know--how will help for Mekong farmers to compete with rivals in their bid to win market shares in China, the Republic of Korea and Japan.

The main cropping systems in Mekong Delta are (1) Rice-livestock farming systems; these are most popular systems in the Mekong Delta. Farmers practice such systems in all agro-ecological regions. Rice is grown for family consumption and marketing. By-products of rice are used for livestock production. (2) The rice-wild fish system, rice-saline water shrimp farming systems; those systems are found most popular in the coastal zones and the Ca Mau peninsula. (3) Rice-upland crops with more than 20 different cropping patterns are found in the sandy bank of the coastal zones. Due to unfavorable conditions of soil, the rice yields are lower compared to those in other regions. The income of farmers in this zone is also very low. (4) Deep-water rice and other crops such as hybrid corn, white bean, soybean and watermelon are popular cropping patterns in the Long Xuyen quadrangle. (5) Farming systems in the Trans-Bassac and fresh water alluvial soil zones include rice-prawn farming system and rice-fish farming system. Those systems can bring highest income for farmers, but due to problems of fry supply, the systems can not be extended to other areas of the Mekong Delta.

\section{SOME PROBLEMS AND CONSTRAINTS OF THE FARMING SYSTEM IN MEKONG DELTA}

The major constraints are flooding at the end of the rainy season, and drought in the dry season. Serious flood damages the fruit production and infrastructure. It creates many difficulties in production and affect also on the crop yields. On the contrary, in the dry season, the Mekong River is at the lowest level, and there may occur water problems such as shortage of water, soil acidification and salinization.

With the increase of use of chemical fertilizer and pesticide in rice production, it causes pollution of water resources in rural area and affects on the environment. At present, because of high price of shrimp, shrimp farming in the coastal area in Ca Mau peninsula zone has been expanding rapidly, and the farmers moving into public mangrove forest, exploiting those area for shrimp farming. That brings the negative impact on environment and creates many biodiversity and social problems. 
Extremely weak physical infrastructure is also one of the big problems. In Mekong Delta rural transportation systems are remaining backward, delaying good exchange, dividing market, increasing transaction cost, and reducing product quality. The current level of physical infrastructure is inadequate to support the prospective increases of agricultural production. Two-thirds of the farms have no access to drying facilities; most of the crop is sun-dried. Storage capacity is about 1 million $\mathrm{m}^{3}$ or $67 \%$ of the total needed. Transportation for moving the crop to market is inadequate.

Lacking of skilled labor and technology is also serious problem in Mekong Delta. Farmers complain that most of them are losing out on income because they are not knowledgeable enough about production and trading rights. They all long for scientific co-operation because it would improve the quality of their produce, reduce costs and raise profits. They also blame that backward traditions in cultivation and inadequate awareness of bio-technology are hindering Vietnam's competitiveness in domestic and international markets. The farming sector needs co-ordination among farmers, scientists and traders for success, but this is not currently happening.

Income of farmers and other living conditions are still low, and the rural development not yet sustainable. The differences in the level of income between urban and rural areas, or between rural areas in different locations have been increasing. The rate of poor households in the rural area in Mekong delta is $11.74 \%$ in 1999 (GSO, 2000b). Poor farmers are vulnerable to disadvantage. They cannot compete with richer farmers for credit, loans and technologies. Increase in unemployment under increasing labor population is becoming an imperative matter (Son, 1998). There exist an increasing trend of landless households that again create many other social problems.

\section{Conclusion}

Mekong Delta was, is and will still play a very important role in development of agriculture of Vietnam. With the great potentials that have been not fully exploited yet, the Mekong Delta should be paid attention on the process of development. The development of the Mekong Delta is very sensitive to the natural resources. A farming system approach for sustainable agricultural development and resource management should be adapted as a routine tool for research and development in the future.

\section{REFERENCES}

Cuc, NS. 1995 Agriculture of Vietnam 1945-1995. Statistical Publishing House, Hanoi General Statistical Office (GSO) 2000a Statistical yearbook 1999. Statistical Publishing House, Hanoi General Statistical Office (GSO) 2000b Vietnam Living Standard Survey 1997-1998. Statistical Publishing House, Hanoi

General Statistical Office (GSO) 2001 Statistical yearbook 2000. Statistical Publishing House, Hanoi General Statistical Office, Department of Agriculture, Forestry and Fishery 2000 Statistical data of Vietnam Agriculture, Forestry and Fishery 1975-2000. Statistical Publishing House, Hanoi.

General Statistical Office, Integrated and Information Department 2000 Statistical data of Vietnam socio-economy 1975-2000. Statistical Publishing House, Hanoi.

Sanh, N. V., V. T. Xuan, T. A. Phong 1998. History and future of farming systems in the Mekong Delta. In "Development of farming systems in the Mekong Delta of Vietnam" Edited by V. T. Xuan, S. Matsui. Ho Chi Minh city publishing house, Sai gon time group, Vietnam Asia Pacific Economic Center, Ho Chi 
Minh city.

Son, D. K. 1998 Development of agricultural production systems in the Mekong Delta. In "Development of farming systems in the Mekong Delta of Vietnam" Edited by V. T. Xuan, S. Matsui. Ho Chi Minh city publishing house, Sai gon time group, Vietnam Asia Pacific Economic Center, Ho Chi Minh city.

Thao, L. B. 1997 Vietnam the country and its geographical regions. The gioi Publisher, Hanoi

The National Institute of Agricultural Planning and Projection of Vietnam (NIAPP) 1987 The legend on the agro-ecological map of Mekong Delta 